\title{
TINGKAT KEMAMPUAN BERPIKIR KRITIS SISWA \\ BERDASARKAN SELF REGULATED LEARNING MELALUI METODE GUIDED DISCOVERY LEARNING
}

\author{
Mauliana Wayudi ${ }^{1}$. Suwatno ${ }^{2}$. Budi Santoso ${ }^{3}$ \\ Universitas Pendidikan Indonesia \\ Email: mauliana.wayudi@upi.edu; suwatno@upi.edu; budisantoso@upi.edu
}

\begin{abstract}
ABSTRAK
Tujuan dari penelitian ini yaitu untuk melihat: 1) pengaruh self regulated learningterhadap kemampuan berpikir kritis siswa melalui penerapan metode pembelajaran guided discovery learning; dan 2) tingkat kemampuan berpikir kritis siswa berdasarkan tingkat self regulated learning melalui metode guided discovery learning.Sampeldalam penelitian ini adalah siswa kelas X IPS SMA Negeri 1 Seunagan sebanyak 35 orang. Pengumpulan data dilakukan dengan penyebaran kuesioner untuk melihat tingkat self regulated learning masing-masing siswa,pemberian tes kepada siswa sebelum dan sesudah pemberian perlakuan dengan metode guided discovery learning. Hasil penelitian yang diperoleh: 1) Dari hasil uji regresi sederhana diperoleh nilai $F$ sebesar 16,548 dengan angka signifikansi 0,000 yang dapat disimpulkan bahwa secara signifikan self regulated learning berpengaruh terhadap peningkatan kemampuan berpikir kritis siswa melalui metode guided discovery learning karna angka sig. < 0,05; 2) Untuk tingkat kemampuan berpikir kritis siswa berdasarkan tingkat self regulated learning diperoleh hasil: (a) siswa dengan tingkat self regulated learning tinggi, memiliki kemampuan berpikir kritis dengan kategori tinggi $(81,52)$; (b) siswa dengan tingkat self regulated learning sedang, memiliki kemampuan berpikir kritis dengan kategori tinggi $(77,5)$; dan (c) siswa dengan tingkat self regulated learning rendah, memiliki kemampuan berpikir kritis dengan kategori sedang $(70,00)$.
\end{abstract}

Kata Kunci: Berpikir Kritis, Self Regulated Learning, dan Guided Discovery Learning.

\begin{abstract}
The purpose of this study is to see: 1) independent learning that is regulated against students' critical thinking abilities through the application of discovery guided learning methods; and 2) the level of students' critical thinking skills based on the level of self regulated learning through the guided discovery learning method. The sample in this study were 35 social studies class X students of SMA Negeri 1 Seunagan. Data collection is done by collecting questionnaires to see the level of learning that is individually set by each student. The results of the study are obtained: 1) From the simple regression results obtained an $F$ value of 16.548 with a significance value of 0.000 which can be concluded that significant independent learning is regulated towards improving students' thinking abilities through methods guided by learning findings because of the numbers sig. <0.05; 2) For the level of critical thinking ability of students based on the level of independent learning the results obtained are: (a) students with a regulated level of independent learning have high critical thinking skills (81.52); (b) students with moderate level of independent
\end{abstract}

Jurnal Edueksos Vol IX, No. 2, Desember 2020

The journal of social and economics education 
learning, having critical thinking skills with a high category (77.5); and (c) students with low levels of self-regulated learning, have the ability to think critically in the medium category (70.00).

Keywords: Critical Thinking, Self Regulated Learning, and Guided Discovery Learning

\section{A. PENDAHULUAN}

Pendidikan memiliki peran yang sangat penting dalam pengembangan dan kemajuan suatu negara. Kemajuan ilmu pengetahuan dan teknologi yang bersifat globalisasi dalam proses pendidikan dianggap sebagai tantangan yang harus ditegakkan oleh setiap negara. Salah satu penekanan tantangan dunia pendidikan saat ini adalah memperkenalkan keterampilan abad ke-21 pada kalangan siswa. Dengan demikian, baik sekolah negeri maupun swastauntuk dapat memastikan setiap siswanyaagar memperoleh pembelajaran yang memunculkan keterampilan berpikir dan penalaran yang sangat penting di abad ke-21 ini (Silva, 2009).

Keterampilan abad ke-21 dapat didefinisikan sebagai seperangkat pengetahuan yang luas, kebiasaan kerja dan sifat yang sangat penting bagi keberhasilan seseorang di era saat ini. Sebagai contoh, dalam proses pembelajaran perguruan tinggi, keterampilan abad ke-21 dapat diterapkan dalam semua bidang pendidikan dan bidang studi, serta juga dapat membantu peserta didik hidup bermasyarakat dan bekerja sukses di abad ke-21 (Moyer, 2016; Rotherham \& Willingham, 2009). Keterampilan abad 21 diperlukan agar siswa dapat memecahkan masalah yang lebih kompleks, berkolaborasi dan berkomunikasi dengan baik, memiliki keterampilan untuk memperoleh informasi secara mandiri, dan mampu beradaptasi serta bersaing dalam perekonomian yang bersifat global saat ini (Gewertz, 2008). Dengan demikian lembaga-lembaga pendidikan di seluruh dunia harus dapat memperkenalkan keterampilan abad ke-21 kepada siswa melalui pendidikan formal (Colardyn \& Bjornavold, 2004).

Secara umum, berpikir kritis dianggap sebagai hal yang penting dalam dunia pendidikan. Psikolog Robert Sternberg mendefinisikan pemikiran kritis secara luas sebagai "proses mental, strategi, dan representasi yang digunakan orang untuk menyelesaikan masalah, membuat keputusan, dan mempelajari konsepkonsep baru. Profesor Pendidikan Michael Scriven dan filsuf Richard Paul 
mendefinisikannya sebagai proses disiplin intelektual dari konseptualisasi aktif danterampil, menerapkan, menganalisis, mensintesis, danatau mengevaluasi informasi yang dikumpulkan, atau dihasilkan oleh, pengamatan, pengalaman, refleksi, penalaran, atau komunikasi, sebagai panduan untuk keyakinan dan tindakan. Secara umum, pemikiran kritis merupakan pemikiran aktif dengan tingkat yang lebih tinggi dan bersifat abstrak (Shaw, 2014). Dengan demikian tidak semua pertanyaan guru dan tanggapan siswa bersifat permanen. Prosedur tanya jawab guru dapat dimulai dari ingatan dasar hingga pemikiran tingkat tinggi.

Saat ini pentingnya mengembangkan keterampilan berpikir kritis siswa dalam pembelajaran telah menjadi salat satu tujuan pendidikan. Guru-guru hendaknya melakukan pergeseran dari pengajaran yang menekankan pada keterampilan berpikir tingkat rendah ke pembelajaran yang menekankan pada keterampilan berpikir tingkat tinggi atau keterampilan berpikir kritis (Tsaparlis \& Zoller, 2003; Lubezki, Dori dan Zoller, 2004). Secara umum diakui bahwa kemampuan untuk berpikir secara kritis menjadi semakin penting bagi keberhasilan dalam kehidupan seiring dengan laju perubahan yang terus meningkat dan seiring dengan meningkatnya kompleksitas dan saling ketergantungan. Karena pendidikan adalah sarana utama dalam mempersiapkan siswa sebagai warga negara masa depan untuk kehidupan yang aktif dan bertanggung jawab dalam masyarakat berbasis teknologi modern kita ini, sekolah di semua tingkatan harus menjadi fokus untuk mengembangkan pemikiran kritis (Costa dalam (Zoller et al., 2010).

Pemikiran kritisberfokus pada peningkatan proses pemikiran seseorang tentang semua bidang kehidupan. Pendukung berpikir kritis berpendapat bahwa orang harus mempertanyakan "argumen yang salah, generalisasi tergesa-gesa, pernyataan kurangnya bukti, klaim kebenaran berdasarkan otoritas yang tidak dapat diandalkan, konsep ambigu atau tidak jelas. (Burbules, 1999). Edward Glaser mengembangkan pandangannya dengan mengkonstruksi pandangan John Dewey(Yaumi \& Ibrahim, 2013: 67) dimana berpikir kritis dipandang:

(1) An attitude of being disposed to consider in a thoughtful way the problems and subject that come within the range of one's experience; 
(2) knowledge of the methods of logical enquiry and reasoning; and (3) some skill in applying those methods. Critical thinking calls for a persistent effort to examine any belief or supposed form of knowledge in the light of the evidence that supports it and the further conclucions to which it tends.

Edward Glaser berpandangan bahwa berpikir kritis adalah suatu sikap yang ingin mempertimbangkan berbagai masalah berdasarkan pengalaman seseorang dengan cara yang bijaksana menunjukkan bahwa berpikir kritis itu bukan hanya menghadirkan suatu sikap keinginan untuk mempertimbangkan sesuatu dalam menyelesaikan masalah, melainkan juga harus dilakukan dengan cara yang bijaksana dan tenggang rasa. Begitu pula dengan pengetahuan tentang metode pemecahan masalah dan alasan logis menunjukkan bahwa untuk berpikir kritis diharuskan adanya pemahaman yang dalam tentang cara-cara ilmiah dan rasional untuk memproduksi dan menghasilkan sesuatu (Yaumi \& Ibrahim, 2013: 67).

Kemampuan berpikir kritis adalah kemampuan berpikir dalam membuat keputusan yang dapat dipercaya dan bertanggung jawab (Redhana, 2010). Kemampuan berpikir kritis berpengaruh terhadap kemampuan seseorang dalam menyelesaikan masalah dalam kehidupan sehari-hari. Oleh karena itu, kemampuan berpikir kritis dapat menumbuhkembangkan kemampuan untuk menyelidiki masalah, mengajukan pertanyaan, dan juga menemukan informasi baru. Kesulitan lain dalam literatur pemikiran kritis adalah mendefinisikan konstruk. Pandangan generalis tradisional mengonseptualisasikan pemikiran kritis sebagai kemampuan luas untuk menafsirkan informasi dan mendekati masalah dengan benar yang dapat diterapkan di berbagai domain (McMillan, 1987; Pascarella \& T., 1989).

Materi pelajaran tidak ada artinya dan tidak relevan ketika menyadari bahwa prinsip pragmatis dapat memiliki makna khsusus di sekolahnya. Siswa akan berpikir lebih baik jika mereka dapat diberikan kondisi yang akan mendorong penerapan pemikiran mereka ke dunia tempat mereka tinggal. Daya tarik yang akan memacu mereka adalah penemuan makna dari ide-ide yang mereka coba kuasai (Lipman, 2003).

Mata pelajaran Ekonomi pada jenjang Sekolah Menengah Atas (SMA) dituntut untuk mempunyai kemampuan pemahaman konsep dan berpikir kritis 
yang digunakan siswa untuk menghadapi berbagai permasalahan yang ada. Tujuan utama dari mata pelajaran ekonomi adalah untuk memahami dunia dan membuat pilihan yang lebih baik serta menyiapkan mereka untuk berperan sebagai pelaku ekonomi di masa depan (Thompson, Butter, \& Asarta, 2011).

Rerata nilai Ujian Nasional (UN) program IPS (Ilmu Pengetahuan Sosial) mata pelajaran ekonomi pada tingkat Nasional, Provinsi dan Kabupaten disajikan dalam Gambar 1.

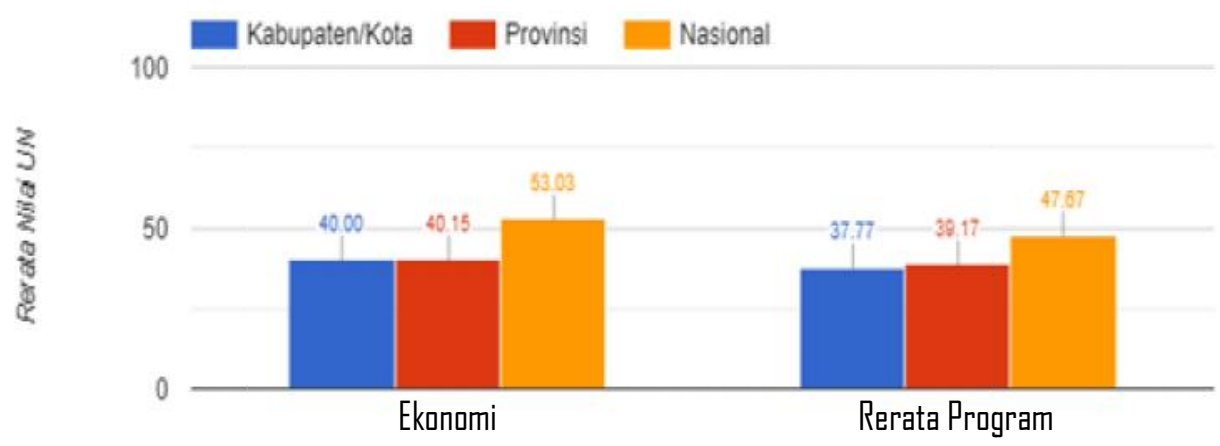

Sumber: Kemdikbud, 2019

Gambar 1Grafik Nilai UN Ekonomi Tahun Ajaran 2018/2019

Gambar 1 menunjukkan rerata nilai UN mata pelajaran Ekonomi tahun ajaran 2018/2019 untuk tingkat Nasional mencapai 53,03, untuk tingkat Provinsi (Aceh) 40,15, tingkat Kabupaten (Nagan Raya) 40,00. Gambar 1 menunjukkan bahwa pencapaian siswa masih tergolong ke dalam kategori kurang.

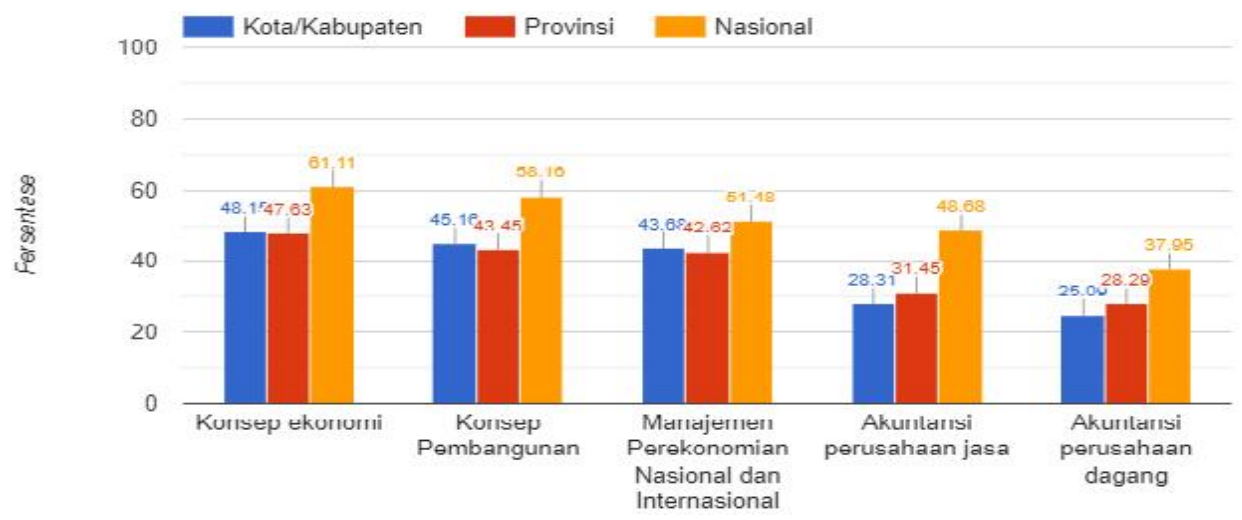

Gambar 2 Grafik Penguasaan Materi UN TA 2018/2019

Gambar 2 menyajikan materi-materi Ujian Nasional mata pelajaran ekonomi. Persentase siswa yang menjawab benar dari kelima materi tersebut masih rendah. Hasil ini memperlihatkan bahwa selama ini siswa masih belum 
terbiasa menyelesaikan soal-soal dengan kognitif yang lebih tinggi yang mengakibatkan lemahnya kemampuan berpikir tingkat tinggi.

Lemahnya kemampuan berpikir tingkat tinggi siswa dapat disebabkan oleh beberapa faktor, salah satu diantaranya adalah proses pembelajaran yang dilaksanakan. Pembelajaran haruslah melibatkan siswa secara aktif serta memfasilitasi siswa untuk dapat menggunakan kemampuan berpikir tingkat tinggi. Disamping itu, sudah menjadi suatu kewajiban bagi guru untuk dapat merancang pembelajaran yang interaktif, inspiratif, menyenangkan, menantang, dan memotivasi siswa untuk berpartisipasi aktif sesuai dengan Permendiknas No 41 Tahun 2007 tentang Standar Proses (Happy \& Widjajanti, 2014).

Metode Guided discovery learning merupakan salah satu metode pembelajaran yang dipercaya dapat mengembangkan kreativitas dan berpikir kritis siswa dalam memecahkan masalah. Belajar penemuan (discovery learning) menurut Jerome Brunner merupakan model pengajaran yang dikembangkan berdasarkan kepada pandangan kognitif dan konstruktivisme. Menurut Sani (2013) discovery adalah menemukan konsep melalui serangkaian data atau informasi yang diperoleh melalui pengamatan atau percobaan. Pembelajaran discovery merupakan metode pembelajaran kognitif yang menuntut guru untuk lebih kreatif menciptakan situasi yang dapat membuat peserta didik belajar aktif menemukan pengetahuannya sendiri.

Penerapan model guided discovery learning dapat memberikan penekanan kondisi belajar dengan suasana aman dan nyaman sehingga siswa dapat belajar secara aktif, siswa dapat menemukan/menyelidiki sendiri rumus-rumus berdasarkan materi yang sedang dipelajari dengan bantuan dari guru dan dapat melatih siswa dalam mengingat materi yang sudah dipelajari sehingga pembelajaran berjalan dengan efektif dan optimal. Dengan kondisi ini diharapkan akan mendorong siswa untuk melakukan proses berfikir logis, kreatif serta proses dalam menyelesaikan masalah akan lebih baik. Konsep-konsep matematika tidak hanya pada kemampuan dalam menghitung akan tetapi membantu dalam kemajuan ilmu pengetahuan dan teknologi.

Model pembelajaran guided discovery learning menurut Eggen adalah suatu model pembelajaran dimana siswa dihadapkan pada situasi yang bebas dalam 
mengapresiasikan dirinya untuk menyelidiki rumus yang digunakan, dimana guru memberi siswa contoh-contoh topik spesifik dan memandu siswa untuk memahami topik tersebut (Lestari, 2017). Model pembelajaran Guided Discovery Learning memiliki ciri khas yaitu siswa dapat menemukan/menyelidiki suatu konsep yang sesuai dengan langkah-langkah yang diarahkan oleh guru. Dengan melakukan suatu penemuan siswa diharapkan dapat meningkatkan peran aktif sehingga terjadinya peningkatan pada pemahaman siswa dalam pembelajaran. Hal ini memungkinkan siswa agar dapat memahami konsep, dan menyelesaikan masalah sesuai dengan indikatornya sehingga hasil belajar siswa menjadi optimal.

Selanjutnya untuk dapat mengoptimalkan implementasi dari metode pembelajaran terhadap kemampuan berpikir kritis, siswa juga harus memiliki regulasi diri atau kemampuan untuk mengontrol perilaku sendiri atau self regulated learning. Hal ini sejalan dengan teori kognitif yang memandang bahwa setiap individu memiliki kemampuan untuk membangun sendiri pengetahuannya dengan jalan berinterakasi secara terus-menerus dengan lingkungannya. Sementara itu Giancarlo dan Facione (2001) menyatakan bahwa terdapat enam kecakapan berpikir kritis utama yang terlibat di dalam proses berpikir kritis di antaranya: 1) interpretasi, 2) analisis, 3) evaluasi, 4) inferensi, 5) eksplanasi, dan 6) regulasi diri (Giancarlo \& Facione, 2001).

Konsep Self Regulated Learning (SRL) merupakan pengembangan dari model pembelajaran sosial yang dicetuskan oleh Bandura pada tahun 1986. Teori model sosial menerima sebagian besar dari prinsip-prinsip teori-teori belajar perilaku, tetapi memberi lebih banyak penekanan pada efek-efek dari isyaratisyarat pada perilaku, dan pada proses-proses mental internal (Joyce \& Weil, 2009). Teori belajar sosial menekankan bahwa lingkungan-lingkungan yang dihadapkan pada seseorang tidak random, lingkungan-lingkungan itu kerap kalau dipilih dan diubah oleh seseorang itu melalui perilaku sendiri.

Teori ini juga menekankan pada usaha mengembangkan kcmampuan peserta didik agar memiliki kecakapan untuk berhubungan dengan orang lain sebagai usaha membangun sikap peserta didik yang demokratis dengan menghargai setiap perbedaan dalam realitas sosial. Menurut Bandura menyiratkan bahwa sebagian besar manusia belajar melalui pengamatan secara selektif dan 
mengingat tingkah laku orang lain. Inti dari teori pembelajaran sosial adalah permodelan (modelling), dan permodelan ini merupakan salah satu langkah paling penting dalam pembelajaran terpadu (Joyce \& Weil, 2009).

Self regulated learning adalah proses bertahap, kompleks, disengaja, dan diarahkan pada tujuan yang berisi komponen kognitif, metakognitif, motivasi, afektif, emosional, sosial, dan kontekstual. Fase pertama adalah definisi tugas, kemudian perencanaan dan penetapan tujuan, diberlakukannya, dan evaluasi. Keyakinan epistemik pribadi, pengetahuan, dan dampak (kognisi epistemik, metakognisi epistemik, motivasi epistemik, dan emosi epistemik) memengaruhi semua fase. Self regulated learning adalah potret yang luas dari konteks di mana pelajar berada, terutama berfokus pada pembelajaran akademik, dan sepenuhnya terikat oleh konteks pembelajaran (Muis, 2007).

Paparan di atas yang menjadi dasar peneliti untuk melihat bagaimana tingkat kemampuan berpikir kritis siswa sekolah menengah atas berdasarkan tingkat self regulated learning serta ingin melihat apakah terdapat pengaruh self regulated learning terhadap tingkat kemampuan berpikir kritis siswa SMA Negeri 1 Seunagan kelas X pada mata pelajaran ekonomi.

\section{B. METODE PENELITIAN}

Metode yang digunakan dalam penelitian ini adalah kuasi eksperimen dengan desain penelitian berupa factorial design. Penelitian ini bermaksud memberikan perlakuan berupa penerapan metode pembelajaran guided discovery learning berdasarkan tingkat self regulated learning. Populasi penelitian ini adalah seluruh siswa kelas X IPS SMAN 1 Seunagan dengan total 97 siswa. Tekhnik pengambilan sampel dalam penelitian ini yaitu menggunakan simple random sampling sehingga diperoleh kelas X IPS 1yang dijadikan sebagai sampel dengan asumsi kelas ini memiliki karakteristik yang sama dengan kelas lainnya sehingga dapat dijadikan perwakilan sebagai sampel dengan jumlah 35 siswa.

Penelitian ini menggunakan kuesioner untuk menentukan tingkat self regulated learning yang disebar pada siswa sebelum siswa memperoleh perlakuan berupa metode pembelajaranguided discovery learning.Dengan demikian terdapat 3 jenis kondisi yaitu self regulated learning siswa tingkat 
tinggi, tingkat sedang dan tingkat rendah.Setelah menerima perlakuan berupa metode pembelajaran guided discovery learning siswa akan diberikan alat tes berisi soal pilihan ganda dengan materi Perkoperasian dalam Perekonomian Indonesia untuk mengukur kemampuan berpikir kritis siswa. Untuk menjawab pertanyaan dalam penelitian ini akan digunakan skor N-Gain post test dan pre test siswa. Analisis data dalam penelitian ini berupa uji normalitas, uji homogenitas, dan uji resgresi sederhana dengan bantuan program SPSS versi 26.

Penelitian ini terdiri dari 3 variabel yaitu independent variable berupa self regulated learning, dependent variable berupa kemampuan berpikir kritis, dan variabel moderator berupa metode pembelajaran guided discovery learning. Untuk lebih jelas dapat dilihat dari Tabel 1 berikut.

Tabel 1. Operasionalisasi Variabel

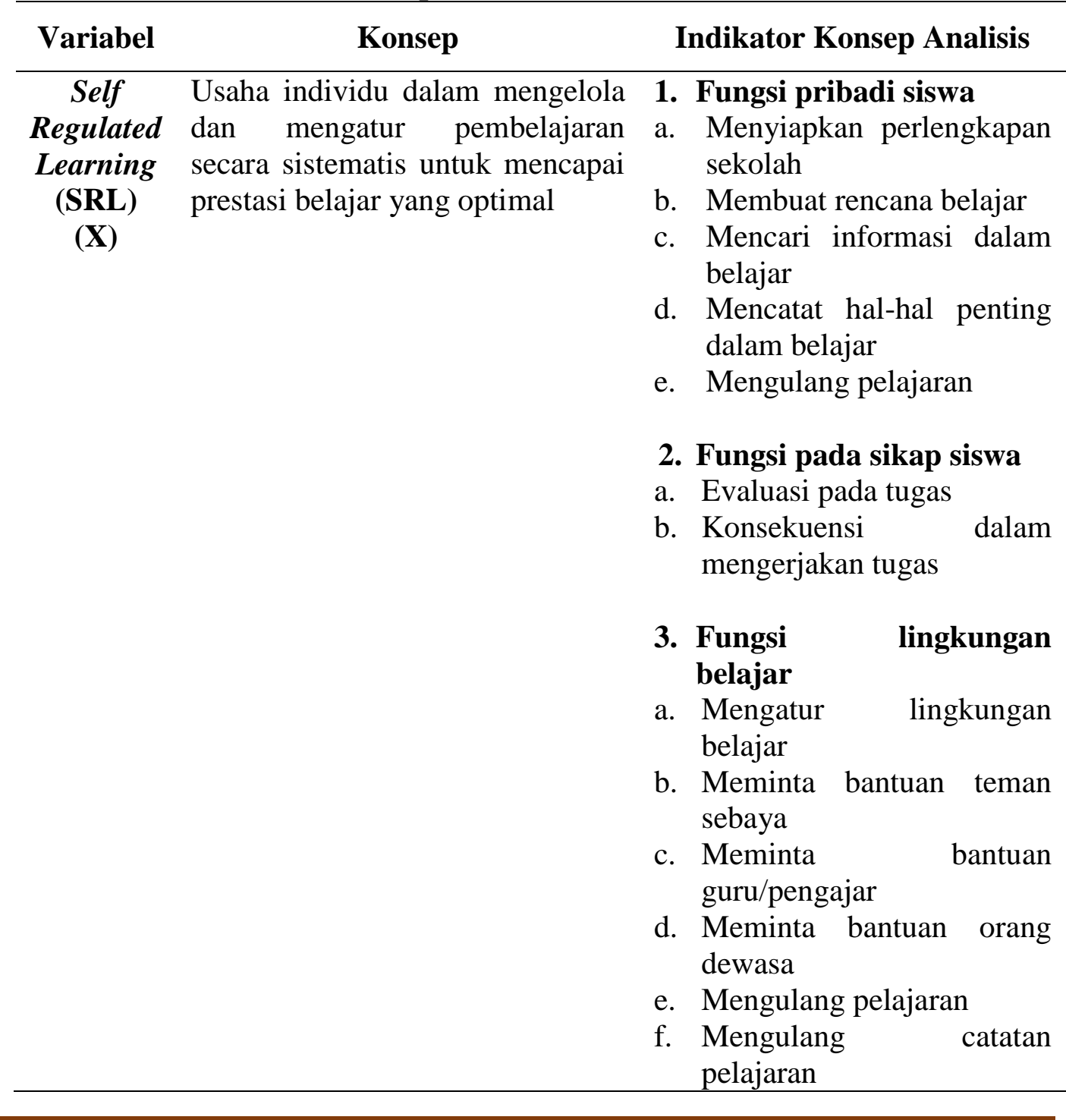




\section{Berfikir Indikator Berpikir Kritis Kritis}

(Y)
1. Memberi sederhana clarification)

2. Membangun Keterampilan dasar (basic support)

3. Membuat kesimpulan (inferring)

4. Membuat penjelasan lebih lanjut clarification)

5. Mengatur strategi dan taktik (strategies and tactics)

Metode Metode guided Discovery

Guided Learning adalah metode

Discovery pembelajaran yang bersifat dua

Learning arah di mana pada proses

(M) pembelajarannya, siswa melakukan penemuan (discovery) dan guru memberikan bimbingan (guided) kepada siswa untuk mengkonstruksi pengetahuan yang baru
1. Merumuskan masalah

2. Menyusun, memproses, mengorganisir, dan menganalisis data yang diberikan

3. Menyusun konjektur

4. Guru memeriksa konjektur siswa

5. Verbalisasi konjektur

Dalam penelitian ini juga akan dilakukan metode deskriptif untuk melihat tingkat kemampuan berpikir kritis siswa kelas X SMA Negeri 1 Seunagan dari perlakuan metode guided discovery dengan self regulated learning pada tingkat tinggi, sedang, dan rendah. Untuk tingkat kemampuan berpikir kritis dianalisis dengan deskriptif kuantitatif. Rata-rata kemampuan berpikir kritis akan dianalisis dengan kriteria yang tercantum pada Tabel 2 .

Tabel 2. Kriteria Rata-Rata Kemampuan Berpikir Kritis Siswa

\begin{tabular}{cc}
\hline Skor & Kriteria \\
\hline $\mathbf{8 6 - 1 0 0}$ & Sangat Tinggi \\
$\mathbf{7 1}-\mathbf{8 5}$ & Tinggi \\
$\mathbf{5 6}-\mathbf{7 0}$ & Sedang \\
$\mathbf{4 1}-\mathbf{5 5}$ & Rendah \\
$<\mathbf{4 0}$ & Sangat Rendah \\
\hline
\end{tabular}

(Adopsi Agip, et al2009)

\section{HASIL DAN PEMBAHASAN}

Penelitian ini memperoleh hasil berupa data pre test dan post test kemampuan berpikir kritis dan hasil terkait tingkat self regulated learning siswa 
kelas X SMA Negeri 1 Seunagan yang telah memperoleh perlakuan metode guided discovery learning. Sementara itu untuk tingkat self regulated learning dilihat dari penskoran dengan kategori tingkat self regulated learning tinggi (74100), self regulated learning sedang (47-73), dan self regulated learning rendah (20-46).

Sebelum dilakukan pengujian pengaruh self regulated learning terhadap kemampuan berpikir kritis siswa yang melalui penerapan metode pembelajaran guided discovery learning, dilakukan terlebih dahulu uji normalitas untuk mengetahui apakah hasil pre test dan post test berdistribusi normal atau tidak dan juga dilakukan uji homogenitas untuk memeriksa apakah skor-skor yang diperoleh dalam penelitian ini mempunyai variasi yang homogen atau tidak. Uji normalitas dan Uji Homogenitas dilakukan dengan bantuan program SPSS 26. Berikut hasil uji normalitas disajikan dalam Tabel 3.

Tabel 3. Test of Normality Kemampuan Berpikir Kritis Siswa

\begin{tabular}{clccc}
\hline & Tingkat & \multicolumn{3}{c}{ Shapiro-Wilk } \\
\cline { 3 - 5 } & SRL & Statistic & df & Sig. \\
\hline \multirow{2}{*}{ Pre_Test } & Tinggi & .949 & 23 & .282 \\
& Sedang & .940 & 8 & .612 \\
& Rendah & .950 & 4 & .714 \\
Post_Test & Tinggi & .897 & 23 & .022 \\
& Sedang & .931 & 8 & .522 \\
& Rendah & .945 & 4 & .683 \\
\hline
\end{tabular}

Dari hasil yang disajikan dalam Tabel 2 bahwa baik data pre test maupun post test memiliki tingkat signifikansi (sig.) > 0,05 yang dapat disimpulkan bahwa data yang diperoleh berdistribusi normal. Namun demikian pada data hasil post test untuk tingkat self regulated learning (SRL) tinggi memiliki signifikansi (sig.) $<0,05$ yang berarti tidak berdistribusi normal. Selanjutnya untuk hasil uji homogenitas dapat dilihat pada Tabel 4.

Tabel 4. Test of Homogeneity Kemampuan Berpikir Kritis

\begin{tabular}{ccccc}
\hline & $\begin{array}{c}\text { Levene } \\
\text { Statistic }\end{array}$ & df1 & df2 & Sig. \\
\hline Pre_Test & .751 & 2 & 32 & .480 \\
Post_Test & 1.295 & 2 & 32 & .288 \\
\hline
\end{tabular}


Dari uji homogenitas, diperoleh signifikansi untuk pre test sebesar 0,480 dan post test sebesar 0,288. Dari hasil keduanya menunjukkan tingkat signifikansi $>0,05$ sehingga baik pre test maupun post test bersifat homogen.

Berdasarkan hasil penelitian, secara keseluruhan rata-rata nilai pre test siswa adalah 37,71 dan rata-rata post test adalah 79,29. Siswa dengan tingkat self regulated learning tinggi terdiri dari 23 siswa, 8 siswa dengan tingkat self regulated learning sedang, dan 4 orang dengan tingkat self regulated learning rendah. Untuk kriteria hasil penskoran $N$-gain dapat dilihat pada Tabel 5.

Tabel 5. Kriteria Interpretasi indeks gain yang dikemukakan oleh Haake

\begin{tabular}{cc}
\hline Skor & Kategori \\
\hline $\mathrm{g} \geq 0,70$ & Tinggi \\
$0,30-0,70$ & Sedang \\
$\mathrm{g} \leq 0,30$ & Rendah
\end{tabular}

Sumber: (Nasharuddin, 2014)

Dari hasil perhitungan nilai $\mathrm{N}$-gain dengan memperhatikan kriteria interpretasi pada Tabel 4 maka diperoleh: (1) hasil dengan kriteria tinggi sebanyak 14 siswa yang terdiri dari 11 siswa dengan tingkat self regulated learning tinggi dan 3 siswa dengan tingkat self regulated learning sedang; (2) hasil dengan kriteria sedang sebanyak 19 siswa yang terdiri 12 siswa dari kelompok self regulated learning tinggi, 5 siswa dari kelompok self regulated learning sedang, dan 2 siswa dari kelompok self regulated learning rendah; (3) dengan kriteria rendah hanya terdiri dari 2 siswa yang merupakan siswa dengan tingkat self regulated learning rendah. Perolehan $N$-gain pada masing-masing tingkat self regulated learning dapat dilihat pada Gambar 3.

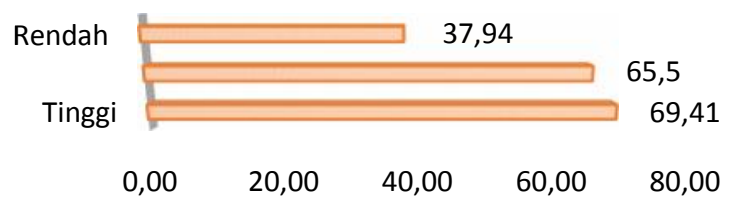

\section{Gambar 3. N-gain (\%) Berdasarkan Self Regulated Learning}

Gambar 3 menunjukkan tingkat perolehan $N$-gain berdasarkan tingkat self regulated learning siswa. Secara keseluruhan perolehan $\mathrm{N}$-gain dari ketiga 
kelompok tingkat self regulated learning siswa adalah 57,63 yang tergolong ke dalam kategori sedang. Dari ketiga kelompok tersebut, yang memiliki tingkat $N$ gain tertinggi yaitu pada kelompok siswa dengan tingkat self regulated learning tinggi.

Selanjutnya untuk melihat pengaruh dari tingkat self regulated learning terhadap peningkatkan kemampuan berpikir kritis siwa dilakukan uji regresi sederhana dengan hasil yang disajikan dalam Tabel 6.

Tabel 6. Hasil Uji Regresi Sederhana

\begin{tabular}{rccccc}
\hline & $\begin{array}{c}\text { Sum of } \\
\text { Squares }\end{array}$ & df & $\begin{array}{c}\text { Mean } \\
\text { Square }\end{array}$ & F & Sig. \\
\hline Regression & .267 & 1 & .267 & 16.548 & $.000^{\mathrm{b}}$ \\
Residual & .532 & 33 & .016 & & \\
Total & .799 & 34 & & & \\
\hline
\end{tabular}

Berdasarkan analisis data yang disajikan pada Tabel 6terlihat bagaimana pengaruh tingkat self regulated learning terhadap peningkatan kemampuan berpikir kritis siswa. Dari hasil uji regresi sederhana diperoleh hasil $\mathrm{F}$ sebesar 16,548 dengan angka signifikansi 0,000 yang artinya lebih kecil dari 0,05. Dengan demikian dapat disimpulkan bahwa tingkat self regulated learning berpengaruh secara signifikan terhadap peningkatan kemapuan berpikir kritis siswa.

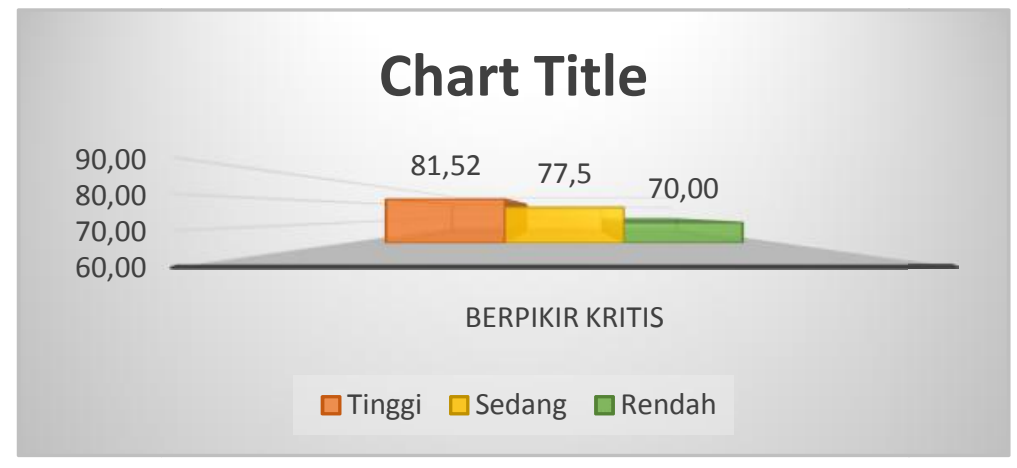

Gambar 4. Diagram Kemampuan Berpikir Kritis Siswa

Pada Gambar4 menyajikan tingkat kemampuan berpikir kritis siswa kelas X SMAN 1 Seunagan berdasarkan tingkat self regulated learning setelah pemberian perlakuan berupa metode guided discovery learning. Dari Gambar 4 secara keseluruhan skor rata-rata kemampuan berpikir kritis siswa adalah 76,34 yang tergolong ke dalam kategori tinggi. Sementara jika dilihat berdasarkan masingmasing tingkat self regulated learning, siswa yang berada pada kelompok tingkat 
self regulated learning rendah memiliki kemampuan berpikir kritis pada kategori sedang.

Kemampuan berpikir kritis yang tinggi memperlihatkan bahwa siswa SMAN 1 Seunagan sudah melibatkan kegiatan seperti menganalisis, menyintesis, membuat pertimbangan, menciptakan dan menerapkan pengetahuan baru pada situasi dunia nyata selama proses pembelajarannya. Seseorang dapat dikatakan memiliki keterampilan berpikir kritis jika dilihat dari beberapa indikator. Ennismembagi indikator keterampilan berpikir kritis ke dalam lima kelompok yaitu: 1) memberikan penjelasan sederhana (elementary clarification), 2) membangun keterampilan dasar (basic support), 3) membuat kesimpulan (inferring), 4) membuat penjelasan lebih lanjut (advanced clarification), 5) mengatur strategi dan taktik (strategies and tactics) (Indrawati, 2012; Zubaidah, 2010).

Dari hasil penelitian ini membuktikan bahwa tingkat self regulated learning dan metode pembelajaran guided discovery learning dapat meningkatkan kemampuan berpikir kritis siswa. Hasil penelitian ini sejalan dengan penelitian yang dilakukan oleh (Purwanto et al., 2012) yang memperoleh hasil bahwa penerapan metode pembelajaran guided discovery dapat meningkatkan kemampuan berpikir kritis siswa. Hal ini ditunjukkan hasil uji gain ternomalisasi yang menunjukkan terjadi peningkatan kemampuan berpikir kritis sebesar 0,40.

Guided discovery learning merupakan sistem dua arah di mana proses pembelajarannya melibatkan siswa dan guru. Siswa melakukan penemuan (discovery) dan guru berpesran dalam memberikan bimbingan (guided) dengan menganalisis kesulitan dalam memecahkan masalah yang dihadapi oleh siswa (Hamalik dalam Widura, et.all: 2015). Dalam penelitiannya (Widura, et.all: 2015) menemukan bahwa sintak guided discovery learningmenuntut siswa untuk lebih baik dalam aspek-aspek berpikir kritis. Rata-rata nilai kemampuan berpikir kritis siswa pada kelas eksperimen yang menerapkan strategi guided discovery learning lebih tinggi dari nilai kemampuan berpikir kritis yang diperoleh siswa kelas kontrol yang menerapkan metode ceramah bervariasi.

Begitu juga halnya dengan self regulated learning yang secara signifikan berpengaruh terhadap peningkatan kemampuan berpikir kritis siswa. Hal ini 
didukung dengan teori kognitif yang memandang bahwa setiap individu memiliki kemampuan dalam membangun sendiri pengetahuannya dengan jalan berinteraksi secara terus-menerus dengan lingkungan. Giancarlo dan Facione (2001) berpendapat bahwa terdapat enam kecakapan berpikir kritis utama yang terlibat di dalam proses berpikir kritis diantaranya (1) interpretasi, (2) analisis, (3) evaluasi, (4) inferensi, (5) eksplanasi, dan (6) regulasi diri (Giancarlo \& Facione, 2001).

Penelitian terkait dengan self regulated learning yang mendukung hasil penelitian ini dilakukan oleh Rosdiana (2018) yang menemukan hasil uji hipotesis dengan nilai $\mathrm{F}=6,423$, dan $p=0,003<0,05$ yang artinya terdapat pengaruh self regulated learning terhadap kemampuan berpikir kritis siswa. Hal serupa juga ditemukan dari penelitian yang dilakukan oleh Ghanizadeh (2011), ia membuktikan bahwa self regulated learning memiliki pengaruh signifikan terhadap kemampuan berpikir kritis $(\mathrm{r}=0,73, \mathrm{p}<0,05)$.

Self regulated learning atau yang dikenal juga dengan kemandirian belajar merupakan suatu proses di mana individu dapat mengambil inisiatif, dengan dan atau tanpa bantuan orang lain, yang dalam hal mendiagnosa kebutuhan belajar, merumuskan tujuan belajar, mengidentifikasi sumber-sumber belajar, memilih dan menerapkan strategi belajar yang sesuai dengan dirinya, serta mengevaluasi hasil belajarnya (Abriyani dalam Nuriali et al., 2018).

\section{KESIMPULAN}

Dari hasil penelitian dan paparan pembahasan terkait analisis data diperoleh kesimpulan bahwa secara signifikan, terdapat pengaruh self regulated learning terhadap kemampuan berpikir kritis siswa melalui penerapan metode pembelajaran guided discovery learning. Hal ini dibuktikan melalui uji regresi sederhana yang diperoleh nilai $\mathrm{F}$ sebesar 16,548 dengan angka signifikansi 0,000 yang artinya lebih kecil dari 0,05. Disamping itu juga terlihat adanya peningkatan rata-rata nilai kemampuan berpikir kritis siwa yang dapat dilihat dari perolehan nilai n-gain yang secara keseluruhan sebesar 57,63 yang termasuk ke dalam kategori sedang. Secara keseluruhan skor rata-rata kemampuan berpikir kritis siswa adalah 76,34 yang tergolong ke dalam kategori tinggi. Tingginya kemampuan berpikir kritis ini memperlihatkan bahwa siswa SMAN 1 Seunagan 
sudah melibatkan kegiatan seperti menganalisis, menyintesis, membuat pertimbangan, menciptakan dan menerapkan pengetahuan baru pada situasi dunia nyata selama proses pembelajarannya. Namun demikian, jika dilihat dari masingmasing tingkat self regulated learning hasil yang diperoleh yaitu: 1) siswa dengan tingkat self regulated learning tinggi, memiliki kemampuan berpikir kritis dengan kategori tinggi; 2) siswa dengan tingkat self regulated learning sedang, memiliki kemampuan berpikir kritis dengan kategori tinggi; dan 3) siswa dengan tingkat self regulated learning rendah, memiliki kemampuan berpikir kritis dengan kategori sedang.

\section{DAFTAR PUSTAKA}

Agip, Z. dkk. (2009). Penelitian Tindakan Kelas untuk Guru SD, SLB dan TK. Bandung: Yrama Widya.

Bellanca, J. A. (2013). The Focus Factor: 8 Essential Twenty-First Century Thinking Skills For Deeper Student Learning. Teacher Collage Press.

Bowyer, C., \& Snowling, M. J. (2011). Assessing children's inference generation: What do tests of reading comprehension measure? British Journal of Psychology, 75(2).

Colardyn, D., \& Bjornavold, J. (2004). Validation of Formal, Non-Formal and Informal Learning: Policy and Practice in EU Member States. European Journal of Education Research, Development and Policy, 39.

Gewertz, C. (2008). States Press Ahead on 21st Century Skills. Education Week, $21-23$.

Ghanizadeh, A. (2011). An Investigation into the Relationship Between SelfRegulation and Critical Thinking Among Iranian EFL Teachers. Technology of Education, 5(3), 213-221.

Giancarlo, C. A., \& Facione, P. A. (2001a). A LOOK ACROSS FOUR YEARS AT THE DISPOSITION TOWARD CRITICAL THINKING AMONG UNDERGRADUATE STUDENTS. Peen State University Press, 50, 27.

Giancarlo, C. A., \& Facione, P. A. (2001b). A LOOK ACROSS FOUR YEARS AT THE DISPOSITION TOWARD CRITICAL THINKING AMONG UNDERGRADUATE STUDENTS. The Journal of General Education, 50(1). https://doi.org/pp. 29-55.

Happy, N., \& Widjajanti, D. B. (2014). Keefektifan Pbl Ditinjau Dari Kemampuan Berpikir Kritis Dan Kreatif Matematis, Serta Self-Esteem Siswa Smp. Jurnal Riset Pendidikan Matematika, 1(1), 48. https://doi.org/10.21831/jrpm.v1i1.2663. 
Indrawati, H. (2012). MENINGKATKAN KETERAMPILAN BERPIKIR KRITIS MAHASISWA MELALUI IMPLEMENTASI MODEL CONTROVERSIAL ISSUES PADA MATA KULIAH EKONOMI SUMBERDAYA MANUSIA DAN ALAM Henny Indrawati. 63-70.

Joyce, B., \& Weil, M. (2009). Models of Teaching (8th ed). Pustaka Belajar.

Lestari, W. (2017). Efektivitas Model Pembelajaran Guided Discovery Learning terhadap Hasil Belajar Matematika. SAP (Susunan Artikel Pendidikan), 2(1), 64-74. https://doi.org/10.30998/sap.v2i1.1724.

Lipman, M. (2003). Thinking In Education (2 ed.). Cambridge University Press.

McMillan, J. H. (1987). Enhancing college students' critical thinking: A review of studies. Research in Higher Education, 26.

Moyer, L. A. (2016). Engaging Students in 21st Century Skills through NonFormal Learning. Virginia Tech.

Nasharuddin. (2014). PENERAPAN MODEL PEMBELAJARAN PENEMUAN BELAJAR FISIKA SISWA KELAS VII B SMP NEGERI 1 BISSAPPU KABUPATEN BANTAENG. 1, 84-95.

Nuriali, W., Busnawir, Samparadja, H., \& Ili, L. (2018). Pengaruh Model Pembelajaran Inkuiri Terbimbing Terhadap The Influence of Guided Inquiry Learning Model Toward Critical Thinking Ability About Mathematics Reviewed From Students' Self Regulated Learning in SMK. Jurnal Pembelajaran Berpikir Matematika, 38(2), 53-64.

Pascarella, \& T., E. (1989). The development of critical thinking: Does college make a difference? Journal of College Student Development, 30, 19-26.

Permendiknas, R. I. (2007). No. 41 Tahun 2007 tentang Standar Proses. Jakarta: Depdiknas.

Purwanto, C. E., Nugroho, S. E., \& Wiyanto. (2012). Penerapan Model Pembelajaran Guided Discovery Pada Materi Pemantulan Cahaya Untuk Meningkatkan Berpikir Kritis. UPEJ (Unnes Physics Education Journal), 1(1). https://doi.org/10.15294/upej.v1i1.768.

Redhana, I. W. (2010). Pengaruh Model Pembelajaran Berbasis Peta Argumen Terhadap Keterampilan Berpikir Kritis Siswa Pada Topik Laju Reaksi. Jurnal Pendidikan dan Pengajaran, 43(17), 141-148.

Rosdiana, G. C. (2018). Pengaruh Implementasi Metode Problem Based Learning Terhadap Kemampuan Berpikir Kritis Siswa Dimoderasi Self Regulated Learning Pada Kompertensi Dasar Menganalisis Perdagangan Internasional. Universitas Pendidikan Indonesia.

Sani, R. A. (2013). Inovasi Pembelajaran. Bumi Aksara. 
Shaw, R. D. (2014). How Critical Is Critical Thinking? Music Educators Journal, 101(2), 65-70. https://doi.org/10.1177/0027432114544376.

Silva, E. (2009). Measuring Skills for 21st-Century Learning. Phi Delta Kappan, 90(9), 630-634.

Tsaparlis, G., \& Zoller, U. (2003). Evaluation of higher vs. lower-order cognitive skills-type examinations in chemistry: implications for university in-class assessment and examinations. University Chemistry Education, 7(2), 50-57.

Yaumi, M., \& Ibrahim, N. (2013). Pembelajaran Berbasis Kecerdasan Jamak (Multiple Intelligences) Mengidentifikasi dan mengembangkan multitalenta anak. Kencana.

Zoller, U., Ben-Chaim, D., Ron, S., Pentimalli, R., Scolastica, S., Chaira, M. S., \& Borsese, A. (2010). The disposition toward critical thinking of high school and university science students: an interintra Israeli-Italian Study. International Journal of Science Education, 22(6), 571-582.

Zubaidah, S. (2010). Berpikir Kritis : Kemampuan Berpikir Tingkat Tinggi yang Dapat Dikembangkan melalui Pembelajaran Sains. 2009, 1-14. 